\title{
Antioxidant and Biological Activities of Leptadenia Hastataethyl Acetate Roots Extracts
}

\author{
Isaac John $\mathrm{U}^{1,2 *}$ and Fasihuddin $\mathrm{AB}^{2}$ \\ ${ }^{1}$ Faculty of Resource Science and Technology, University of Malaysia Sarawak, Malaysia \\ 2Department of Biochemistry, Federal University Wukari, Taraba State, Nigeria
}

*Corresponding author: Isaac John Umaru, Universiti Malaysia Sarawak, Kota

\section{Research Article}

Volume 2 Issue 1

Received Date: June 26, 2018

Published Date: July 09, 2018

Samarahan Malaysia, Kuching, Sarawak, Malaysia, Tel: +6082581009; Email: umaruisaac@gmail.com

\section{Abstract}

Background: Leptadenia hastata (Pers) Decne is one of the most important medicinal plants in West African traditional medicine for the treatment of inflammation, Ant gonorrhea, stomach ache, hypertension, catarrh, skin diseases, trypanosomiasis and Wound healing. Much attention has been paid to this medicinal plant because of its traditional uses. The aim of the study was to evaluate antioxidant and biological activity of the extract obtained from the ethyl acetate extract of the roots of Leptadenia Hastata (Pers.) Decne.

Material and Method: Antioxidant activity of extracts was evaluated by DPPH and the bacterial effect of the plant Leptadenia hastata was evaluated for antimicrobial activity in vitro by agar desk diffusion method with four standard bacterial strains (Staphylococcus aureus, Escherichia coli, Salmonella typhi, Kleibsilia pneumonia).

Result: The ethyl acetate possessed strong radical scavenging activity (IC501.889). The extracts were also effective against all Gram-positive and Gram negative bacteria tested, especially for Staphylococcus aureus and Escherichia coli with an inhibition potential of $1.03 \pm 0.12$ and $1.30 \pm 0.10$ respectively at $500 \mathrm{ppm}$.

Conclusion: These findings give a scientific basis to the traditional usage of Leptadenia hastata (Pers) Decne, also showing its potential as rich sources of natural antioxidant compounds. Thus is a potential candidate to be used as an antioxidant agent, for treatment of other ailment as well as infectious diseases.

Keywords: Antioxidant; Roots; DPPH; Leptadenia hastata; Bacterial

\section{Introduction}

The multiple roles of wild traditional vegetables as both food and medicinal sources have been widely used for health care today, the search for natural compounds rich in antioxidant and antimicrobial properties is escalating due to their medicinal importance in controlling many related chronic disorders such as cancer and cardiovascular diseases.

Antioxidants aid in the prevention by scavenging the excess free radicals in the body which has increased the interest in the use of antioxidative nutritional substances $[1,2]$ body against some diseases caused by oxidative 


\section{Medicinal \& Analytical Chemistry International Journal}

imbalan. Numerous studies showed that using of some vitamins, minerals, and other food constituents with antioxidant activity can protect our ce and free radicals such as cardiovascular disease and the aging process [36]. Antioxidants can decrease. Natural products are very rich sources of natural antioxidant agents

Leptadenia-hastata (Pers.) Decne is a perennial plant of the family of Asclepediacea, the plant is edible nondomesticated vegetable and it is collected in wild throughout Africa. It is a voluble herb with creeping latex stems, glabescent leaves, glomerulus and racemes flowers as well as follicle fruits. The leaves are up to $10 \mathrm{~cm}$ long, mostly ovate and light green. The flowers are cream or yellowish green [7]. Leptadenia hastata is typically grown in tropical dry lands in sandy soil. Wild foods like this plant provide food security during seasonal changes and are used medicinally in many areas. The plant belongs too many of the root-type famine-food plants; they are drought tolerant and can stay in the soil intact for a long time.

The vernacular names for Leptadenia hastata include; hagalhadjar in Arabic and in Chad, yadiya in Hausa in Nigeria and Niger, while in kusume hayla in Ethiopia, ekamongo from Turkana in Kenya, Moore people call it lolongo in Burkina Faso, tarhat or darhat from Wolof in busumba, amata from Jola in Senegal, and Bambara's call it nzongne in Mali [8]. It is a very drought-resistant plant, and can grow with 100 to $450 \mathrm{~mm} /$ year. This plant can tolerate high $\mathrm{pH}$ and high exchangeable sodium and potassium within the environment [9]. The leaves are edible, young leaves are collected, washed and cooked before consumption. In Alduba village, HamerBenaworeda and South-Omo Farmers deliberately grow the species in their homes as food readily available [10].

Local healers use the plant for Ant gonorrhea, stomach ache, hypertension, catarrh, skin diseases, trypanosomiasis, Wound healing and as vegetable for nutrient [11]. The breeders commonly used the leaf and stems for the treatment of parasites and against placental retention among their animals $[12,13]$. Most important effects of these plants are because of compounds, such as alkaloids, tannins, flavonoids, terpenoids, saponins, and phenolic compounds. The plants are now in great demand in the developing world for primary health care not because they are inexpensive but because of their therapeutic, performance, better compatibility and acceptability with human body with low toxicity and minimal side effects [14]. The aim of the study was to evaluate antioxidant and biological activity of the extract obtained from the ethyl acetate extract of the roots of Leptadenia Hastata (Pers.) Decne.

\section{Material and Methods}

\section{Chemicals}

All chemicals used in this research were obtained from SIGMA. Standard antibacterial agent $(30 \mu \mathrm{g})$ tetracycline, antimicrobial susceptibility test discs and Nutrient agar (CM0003) were obtained from Oxoid Ltd, Wade Road, Basingstoke, Hants, RG2 8PW, UK.

\section{Preparation of Test Samples}

The crude extracts (Ethyl acetate) of Leptadenia hastata was used in antibacterial and antioxidant activity, the ethyl acetate crude extracts were tested by disc diffusion method on nutrient agar medium as described by Pundir \& Jain [15]. Exactly $3 \mathrm{mg}$ of the crude sample was dissolved homogeneity in $3 \mathrm{~mL}$ of methanol giving a stock solution of $1000 \mu \mathrm{g} / \mathrm{mL}$. Different volumes from the stock solution were taken, amounted to $25,50,100,250$, $500,1000 \mathrm{ppm}$ each, and dissolved in $5 \mathrm{~mL}$ of methanol to make final concentration respectively.

\section{Preparation of Agar Plates}

Preparation of agar plates was performed based on method described by Pundir \& Jain [15] as reported by Umaru IJ, et al. [14]. Nutrient agar was prepared according to manufacturer's instruction with $14 \mathrm{~g}$ of dried agar dissolved in $500 \mathrm{~mL}$ distilled water. The agar solution was heated until boiling followed by sterilization in autoclave at $121^{\circ} \mathrm{C}$. The agar solution was then poured into a sterile petri plate and allowed to cool down and forming a gel. The plate was divided into eight sections by making a line marking on the outside surface of the plate. The eight sections were for each test samples namely the $25,50,100,250,500,1000 \mathrm{ppm}$ samples, tetracycline $30 \mu \mathrm{g}$ (positive control) and methanol (negative control). The plate was sealed using parafilm and keep chilled at $4^{\circ} \mathrm{C}$ upon bacteria inoculation.

\section{Preparation of Bacteria Broth}

Several selected bacteria were used to evaluate the antibacterial activities of the crude extracts of Leptadenia hastata, Escherichia coli, Salmonella typhi, Staphylococcus aureus and Kliebselia pneumonia were obtained from the stock culture provided by Virology Laboratory, University Malaysia Sarawak, the nutrient broth was prepared according to manufacturer's instruction, with $2.6 \mathrm{~g}$ of the dried broth dissolved in $200 \mathrm{~mL}$ distilled water followed 


\section{Medicinal \& Analytical Chemistry International Journal}

by sterilization in autoclave at $121^{\circ} \mathrm{C}$. The bacterial was sub cultured in a $10 \mathrm{~mL}$ of broth, each in universal glass bottle for 16 hours inside an incubator equipped with shaker at $37^{\circ} \mathrm{C}$ [16]. After 16 hours' incubation, turbidity (optical density/OD) of the bacterial broth was measured by using UV mini spectrophotometer (model 1240 of Shimadzu brand), comparable to that of nutrient broth standard tube for further use [17]. Measurement was performed at wavelength $575 \mathrm{~nm}$ and the bacterial broth was ready to be used when its turbidity was between OD 0.6 to 0.9 . Nutrient broth was used to adjust the turbidity until the desired value was obtained.

\section{Plate Inoculation}

Inoculation of the bacteria was carried out in a biohazard cabinet and the procedure was based on method described by Umaru IJ, et al. [14]. Approximately $1 \mathrm{~mL}$ of the ready bacterial broth was transferred into mini centrifuge tubes. A sterile cotton swap was dipped into the mini centrifuge tube containing bacteria broth and streaked over entire of the agar plate surface, performed in 4 different directions. The agar plate was then left for 5-10 minutes before applying the test samples. The disc used was $6 \mathrm{~mm}$ diameter. A volume of $10 \mu \mathrm{L}$ of the test samples of concentration $25,50,100$, $250,500,1000 \mathrm{ppm}$ were each pupated onto the discs and placed onto the agar plate by using sterile forceps and gently pressed to ensure contact. Next to be placed on the agar plate was the disc pupated with methanol as negative control, followed by $30 \mu \mathrm{g}$ of tetracycline as standard antibacterial agent (positive control). The plates were left at room temperature for 10 minutes to allow the diffusion of the test samples and the standards into the agar. Each crude extract was tested in triplicate for each bacterium used. The plate samples were then incubated at $37^{\circ} \mathrm{C}$ for 24 hours before the inhibition zone around every sample disc being examined. The inhibition zone was measured in diameter to indicate the presence of antibacterial activity for each sample, as compared to the positive control.

\section{Statistical Analysis}

Experimental results are expressed as means \pm S.D. All measurements were in triplicate. The analysis was done using the software-SPSS one-way ANOVA. The IC50 values were calculated using Prism 6 software.

\section{Result and Discussion}

\section{Results}

The issue of antibacterial resistance emanating has led to the search for new antimicrobial agents. Due to the problem of microbial resistance to antibiotics, attention is given toward biologically active components isolated from plant species commonly used as herbal medicine, as they may offer a new source of antimicrobial activities [14]. Our search for antioxidant and antibacterial activity from this plant Leptadenia hastata ethyl acetate extract revealed an antioxidant and antibacterial activity. The results of antioxidant and antibacterial tests of the plant extracts are as listed in Tables $1 \& 2$ below.

\section{Results}

\begin{tabular}{|c|c|c|c|c|c|}
\hline Plant parts & Crude Extracts & Calibration equation & $\mathbf{R}^{\mathbf{2}}$ & $\mathbf{I C}_{\mathbf{5 0}}(\boldsymbol{\mu g} / \mathbf{m L})$ & $\mathbf{L o g}_{\mathbf{I C}} \mathbf{5 0}$ \\
\hline Roots & Control & $2.638 \mathrm{x}-0.03159$ & 0.9937 & 57.89 & 1.763 \\
\hline & Ethyl acetate & $7.435 \mathrm{x}-0.02965$ & 0.9886 & 79.34 & 1.889 \\
\hline
\end{tabular}

Table 1: IC50 value of Roots.

\begin{tabular}{|c|c|c|c|c|c|c|c|}
\hline Extract & Control & 25ppm & 50ppm & 100ppm & 250ppm & 500ppm & 1000ppm \\
\hline $\begin{array}{c}\text { Staphylococcus } \\
\text { aureus }\end{array}$ & $2.05 \pm 0.02$ & $0.47 \pm 0.06$ & $0.60 \pm 0.10$ & $0.77 \pm 0.06$ & $0.90 \pm 0.00$ & $1.03 \pm 0.12$ & $1.20 \pm 0.10^{\mathrm{b}}$ \\
\hline E. coli & $2.06 \pm 0.01$ & $0.77 \pm 0.06^{\mathrm{a}}$ & $0.90^{\mathrm{a}} \pm 0.00$ & $0.83^{\mathrm{a}} \pm 0.06$ & $1.07 \pm 0.15$ & $1.30 \pm 0.10^{\mathrm{a}}$ & $1.23 \pm 0.12^{\mathrm{a}}$ \\
\hline Salmonella typhi & $2.06 \pm 0.10$ & $0.43 \pm 0.06$ & $0.50 \pm 0.10$ & $0.43 \pm 0.06$ & $0.57 \pm 0.06$ & $0.67 \pm 0.06$ & $0.73 \pm 0.06$ \\
\hline $\begin{array}{c}\text { Kleibsilia } \\
\text { pneumonia }\end{array}$ & $2.07 \pm 0.03$ & $0.45 \pm 0.07$ & $0.53 \pm 0.06$ & $0.57 \pm 0.06$ & $0.77 \pm 0.06$ & $0.77 \pm 0.06$ & $0.80 \pm 0.10^{\mathrm{b}}$ \\
\hline
\end{tabular}

Table 2: Effect of Ethyl-acetate Root Extract of Leptadenia hastata.

Values are Mean \pm SD for three determinations

a. Significantly $(\mathrm{p}<0.05)$ higher compared to different extract at the same concentration

b. Significantly $(\mathrm{p}<0.05)$ lower compared to the control 


\section{Medicinal \& Analytical Chemistry International Journal}

\section{Discussion}

The study revealed in DPPH radical scavenging activity model, ethyl acetate extracts showed high activity than standard compound. IC50 values of the samples was $1.889 \mu \mathrm{g} / \mathrm{mL}$ while the IC50 values for ascorbic acid, was $1.763 \mu \mathrm{g} / \mathrm{mL}$. The polyphenolic content in the extracts may correlate to their good DPPH radical scavenging activity. It has been assumed that phenol and flavonoid can quench DPPH radical via hydrogen- or electrondonation mechanism and changes its colour from violet to yellow. Antioxidant is defined as any substances which are able to perform this reaction.

The antibacterial activity of the extract against the tested species of microorganisms (Escherichia coli, Salmonella typhi, Staphylococcus aureus and Kliebselia pneumonia) between concentration ranges for 25 to $1000 \mathrm{ppm}$. The studies revealed that the extracts possess antibacterial activity in a concentration dependent manner against the test organisms and were comparable with the standard drug.

According to the results of disc diffusion assay, this root extract of the plant Leptadenia hastata has active compounds that are effective for the prevention of infections caused by these bacteria Escherichia coli, Salmonella typhi, Staphylococcus aureus and Kliebselia pneumonia. The inhibition yielded at concentration 25$250 \mathrm{ppm}$ was found to be active against all tested strains under study. However, the extract showed higher significant antibacterial activity against Escherichia coli, and Staphylococcus aureus over the other pathogens with an inhibition value of $1.20 \pm 0.10 \mathrm{~mm}$ and $1.23 \pm 0.12 \mathrm{~mm}$ respectively. Though, the extract showed moderate activity at all concentration on the bacterial species, the potency exhibited less significant activity against Escherichia coli and Kleibsilia pneumonia. However, the antioxidant potential of this which showed to be high than the control may accounts for the potent antibacterial activity of the extract. This implies that it may also possess potent antibacterial activity.

\section{Conclusion}

The result of this study showed that Leptadenia hastata (Pers) Decne extract contains bioactive components. Potentially, these compounds have the most important applications against human pathogens. The results of tests from various concentration and the presence of antioxidant component of the leaf extract indicate that the leafs have some measurable inhibitory action against gram-positive and gram negative bacteria.

\section{Conflict of Interests}

All authors have none to declare.

\section{References}

1. Gigante DP, Buchweitz M, Helbig E, Almeida AS, Araújo CL, et al. (2007) Randomized clinical trial of the impact of a nutritional supplement "multimixture" on the nutritional status of children enrolled at preschools. J Pediatr (Rio J) 83(4): 363-369.

2. Simpore J, Kabore F, Zongo F, Dansou D, Bere A, et al. (2006) Nutrition rehabilitation of undernourished children utilizing Spiruline and Misola. Nutr J 5: 3.

3. Wu LC, Ho JA, Shieh MC, Lu IW (2005) Antioxidant and antiproliferative activities of Spirulina and Chlorella water extracts. J Agric Food Chem 53(10): 4207-4212.

4. Hsia J, Heiss G, Ren H, Allison M, Dolan NC, et al. (2007) Calcium/vitamin D supplementation and cardiovascular events. Circulation 115(7): 846-854.

5. Luchsinger JA, Tang MX, Miller J, Green R, Mayeux R (2007) Relation of higher folate intake to lower risk of Alzheimer disease in the elderly. Arch Neurol 64(1): 86-92.

6. Marcason W (2007) Is supplementation of B vitamins still recommended to reduce the risk of heart disease?. J Am Diet Assoc 107(3): 525.

7. Umaru IJ, Badruddin FA, Assim ZB, Umaru HA (2017) Antifungal Activity of Leptadenia hastata (Pers) Decne Leaves Extract. Int J Pure App Biosci 5(6): 1418.

8. Thomas SD (2012) Leptadenia hastata: A Review of its Traditional uses and its Pharmacological Activity. Med Chem 2: 148-150.

9. Afifi MS, Hassan MA, Ali EA, Badria FA, Mahmood EF (2002) Phytochemical and Biological investigation of Leptadenia Pyrotechnica decne growing in Egypt. Journal of Pharmaceutical Sciences 18: 122-138.

10. Freiberger CE, Vanderjagt DJ, Pastuszyn A, Glew RS, Mounkaila G, et al. (1998) Nutrient content of the edible leaves of seven wild plants from Niger. Plant Foods for Human Nutrition 53(1): 57-69. 


\section{Medicinal \& Analytical Chemistry International Journal}

11. Dambatta SH, Aliyu BS (2011) A survey of major ethno medicinal plants of kano north, Nigeria, their knowledge and uses by traditional healers. Bayero Journal of Pure and Applied Sciences 4(2): 28-34.

12. Bayala B, Telefo PB, Bassole IHN, Tamboura HH, Belemtougri RG, et al. (2011) Anti-spermatogenic activity of Leptadenia hastata (Pers.) Decne leaf stems aqueous extracts in male wistar rats. Journal of Pharmacology and Toxicology 6(4): 391-399.

13. Arbonnier M (2000) Arbres, Arbustes et Lianes des Zones Sèches d'Afrique de l'Ouest. 1st(Edn), CIRAD Publishers, Paris, pp: 541.

14. Umaru IJ, Badruddin FA, Assim ZB, Umaru HA (2008) Antibacterial and Cytotoxic Actions of Chloroform Crude Extract of Leptadenia hastata (Pers) Decnee. Clin \& Med Biochemistry 4(1): 139
15. Pundir RK, Jain P (2010) Comparative studies on the antimicrobial activity of black pepper (Piper nigrum) and turmeric (Curcuma longa) extracts. International Journal of Applied Biology and Pharmaceutical Technology 1(2): 491-501.

16. Mahesh B, Satish S (2008) Antimicrobial activity of some important medicinal plant against plant and human pathogens. World Journal of Agricultural Sciences 4: 839-843.

17. Vandepitte J, Engback K, Piot P, Heuck CC (1995) Basic Microbiology Procedures in Clinical Bacteriology. World Health Organization, Geneva, pp: 85.

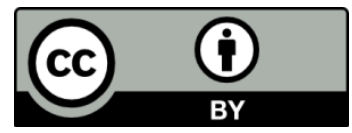

